\title{
Aplikasi Sistem Informasi Geografis Pariwisata Kabupaten Karanganyar Berbasis Android
}

\author{
Sutariyani*1, Robby Rachmatullah ${ }^{2}$, Nur Eka Prase tyowati ${ }^{3}$ \\ 1,2,3 Program Studi Sistem Informasi, STMIK AUB, Surakarta, Indonesia \\ e-mail: *1tari.yani@stmik-aub.ac.id, ${ }^{2}$ robby_r@stmik-aub.ac.id
}

\begin{abstract}
Abstrak
Kabupaten Karanganyar terletak di lereng Gunung Lawu di sisi barat, atau disebelah timur kota Solo atau Surakarta. Dengan keindahan alamnya, Kabupaten Karanganyar memiliki potensi pengembangan pariwisata yang sangat tinggi, terutama di bidang alam dan sejenisnya. Potensi wisata yang dimiliki Kabupaten Karanganyar sangat disayangkanjika tidak didukung dengan penyediaan layanan informasi wisata tentang jalur yang harus dilewati. Dengan banyaknya smartphone yang saat ini berkembang dapat dimanfaatkan untuk meningka tkan jumlah kunjungan wisata.

Penyediaan layanan informasi wisata yang baik terutama di Kabupaten Karanganyar akan memberikan dampak pada peningkatan jumlah kunjungan wisatawan yang berpengaruh pula pada industri wisata lain dan sektor-sektor yang terkait. Sistem informasi geografis Kabupaten Karanganyar nantinya akan memberikan informasi dalam bentuk peta objek wisata sehingga pengguna dapat dengan mudah menemukan rute berupa lokasi dan estimasi jarak dan waktu ke objek wisata yang dituju.

Teknik pengumpulan data dilakukan dengan observasi dan dokumentasi. Adapun analisis datanya dengan menggunakan analisis PIECES. Aplikasi ini mampu memberikan informasi posisi pengguna dan menampilkan lokasi wisata dimana pengguna berada pada saat itu dan dapat diakses oleh siapa saja tanpa perlu login. Aplikasi juga dapat menampilkan estimasi jarak dan waktu tempuh antara pengguna dengan lokasi objek wisata.
\end{abstract}

Kata kunci-Sistem Informasi Geografis, Smartphone, PIECES

Karanganyar Regency is located on the slope of Mount Lawu on the west side, or east side of Solo or Surakarta. With the natural panorama, Karanganyar Regency has a very high tourism development potential, especially in panorama and the others. The potential of Karanganyar Regency is unfortunate if not supported by the provision information services about the path must be passed.

The provision of good tourist information services Karanganyar Regency will have an impact on the increasing number of tourist arrivals that also affect other tourism industries and related sectors. Smartphone can ulitized to increase the number of tourist visits. Geographic information system of Karanganyar Regency will provide information by portable maps that can attractions tourist so users can easily find the route.

The data collection is take byobservation and documentation. Data analysis using by PIECES analysis. Application can provide user position information and display the location where the user at that time and can be accessed by anyone without login. The app can show approximate distance and travel time between user and object location.

Keywords - Geographic information system, smartphone, PIECES 


\section{PENDAHULUAN}

Pariwisata adalah aktivitas perjalanan yang dilakukan oleh sementara waktu dari tempat tinggal semula ke daerah tujuan dengan alasan bukan untuk menetap atau mencari nafkah melainkan hanya untuk memenuhi rasa ingin tahu, menghabiskan waktu senggang atau libur serta tujuan-tujuan lainnya (Meyers, 2009).

Kabupaten Karanganyar terletak di lereng Gunung Lawu di sisi barat, atau disebelah timur kota Solo atau Surakarta. Dengan keindahan alamnya, Kabupaten Karanganyar memiliki potensi pengembangan pariwisata yang sangat tinggi, terutama di bidang alam dan sejenisnya.

Potensi yang dimiliki kabupaten Karanganyar sendiri meliputi: Hutan wisata, wisata alam, sumber air panas, goa, bumi perkemahan, peninggalan purbakala, ziarah, bangunan bersejarah, wisata buatan, kolam renang dan pemancingan. Sistem Informasi Pariwisata Kabupaten Karanganyar yang ada saat ini hanya memberikan informasi berupa lokasi dan fasilitas yang ada. Dengan banyaknya potensi wisata yang dimiliki, sangat disayangkan jika tidak didukung dengan adanya penyedia layanan informasi wisata khususnya tentang jalur yang harus dilewati untuk menuju ke suatu obyek wisata serta pemetaan lokasi obyek wisata itu sendiri. Penyediaan layanan informasi wisata yang baik terutama di Kabupaten Karanganyar akan memberikan dampak pada peningkatan jumlah kunjungan wisatawan yang berpengaruh pula pada industri wisata lain dan sektor-sektor yang terkait.

Berkembangnya berbagai tipe smartphone berbasis Android mendorong kebutuhan informasi dan mobilitas masyarakat semakin meningkat. Berbagai kebutuhan komunikasi dan informasi dimanfaatkan secara efisien melalui smartphone berbasis Android ini. Meningkatnya mobilitas masyarakat terhadap kebutuhan teknologi informasi dapat dimanfaatkan untuk meningkatkan jumlah kunjungan wisata di Kabupaten Karanganyar. Teknologi informasi yang dapat dimanfaatkan adalah sistem informasi geografis menggunakan platform Android.

Dengan dibangunnya Sistem Informasi Geografis Pariwisata Kabupaten Karanganyar Berbasis Android ini nantinya akan memberikan informasi dalam bentuk peta obyek wisata yang ada di Kabupaten Karanganyar yang dapat digunakan oleh pengguna (wisatawan dan atau calon wisatawan) dapat dengan mudah menemukan rute jalan atau jalur menuju obyek wisata. Dengan adanya kemudahan yang didapat, maka akan menambah jumlah wisatawan yang berkunjung ke Kabupaten Karanganyar untuk berwisata sehingga dapat memberikan kontribusi pada meningkatnya pendapatan daerah dan sektor lainnya yang terkait. Untuk selanjutnya dalam penyusunan skripsi ini penulis mengambil judul "Sistem Informasi Geografis Pariwisata Kabupaten Karanganyar Berbasis Android".

\section{METODE PENELITIAN}

\subsection{Metode Observasi}

Teknik observasi adalah teknik pengumpulan data dengan cara peneliti melakukan pengamatan secara langsung di lapangan. Pengamatat disebut observer yang diamati disebut observer. Metode observasi merupakan metode pengumpul data yang dilakukan dengan cara mengamati dan mencatat secara sistematik gejala-gejala yang diselidiki (Supardi, 2006).

\subsection{Teknik Kuesioner}

Angket atau kuesioner merupakan suatu teknik pengumpulan data secara tidak langsung (peneliti tidak langsung bertanya jawab dengan responden). Instrumen atau alat pengumpulan datanya juga disebut angket berisi sejumlah pertanyaan-pertanyaan yang harus dijawab atau direspon oleh responden (Sutopo, 2006). Responden mempunyai kebebasan untuk memberikan jawaban atau respon sesuai dengan persepsinya.

\subsection{Metode Wawancara}

Metode wawancara adalah proses tanya jawab dalam penelitian yang berlangsung secara lisan dalam mana dua orang atau lebih bertatap muka mendengarkan secara langsung informasi-informasi atau keterangan-keterangan (Supardi, 2006). 


\subsection{Diagram Konteks sistem}

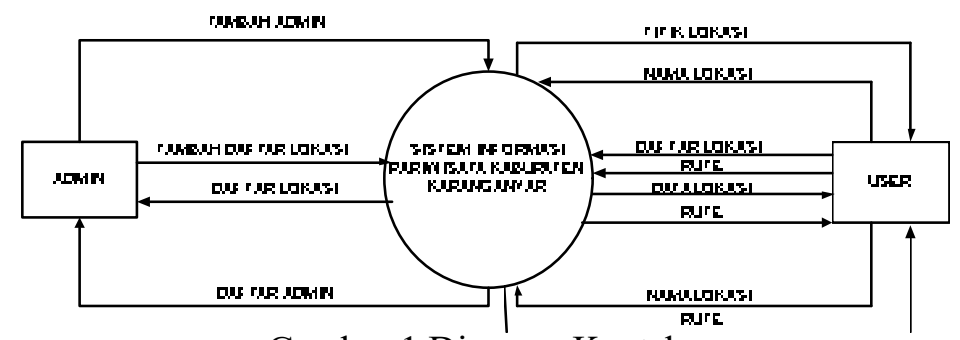

Gambar 1 Diagram Konteks

Gambar 1 menunjukkan bahwa sistem ini berinteraksi dengan 2 entity, yaitu user dan Admin. User dapat melakukan input alamat atau nama objek wisata dan rute sehingga user dapat melihat daftar lokasi yang akan dituju. User juga dapat menetapkan lokasi awal dan memilih objek wisata sehingga user dapat melihat rute yang akan dilalui untuk menuju lokasi wisata. Admin dapat menambahkan daftar lokasi wisata baru atau mengubah, menghapus data lokasi yang ada. Relasi Tabel database pada sistem yang dibuat seperti pada Gambar 2.

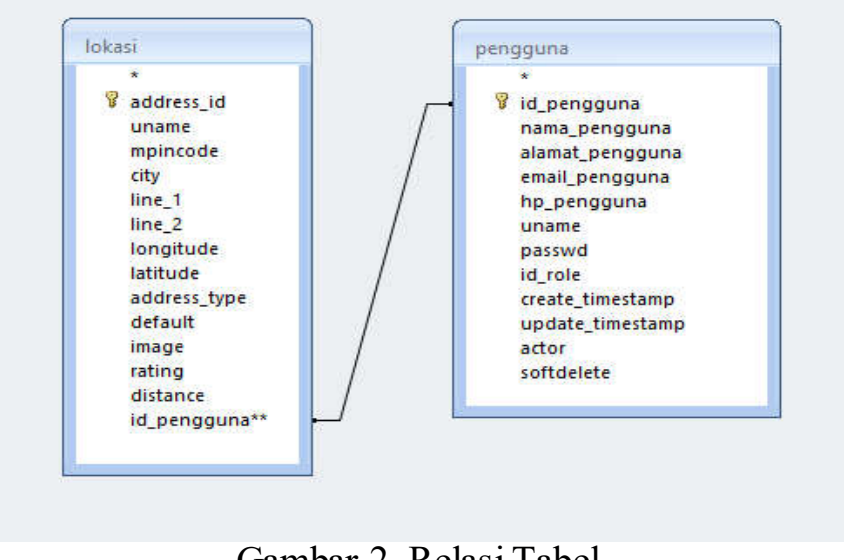

Gambar 2. Relasi Tabel

\section{HASIL DAN PEMBAHASAN}

\subsection{Halaman User}

\subsubsection{Halaman User}

Saat sistem diakses atau dijalankan oleh pengguna, muncul halaman utama (home). Pengguna dari sistem ini adalah user atau calon wisatawan. 


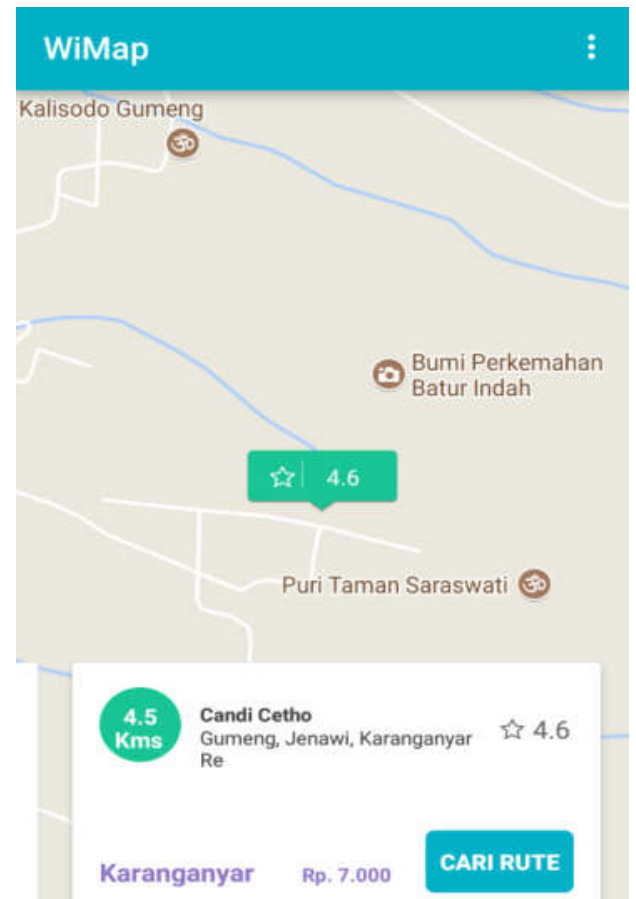

\subsubsection{Halaman Utama User}

Gambar 3. Halaman Utama

Pada halaman utama terdapat menu yang dapat diakses oleh user yang terdapat di pojok kanan atas halaman, yaitu: Home, Daftar Lokasi Wisata, Cari Lokasi, Petunjuk Arah.

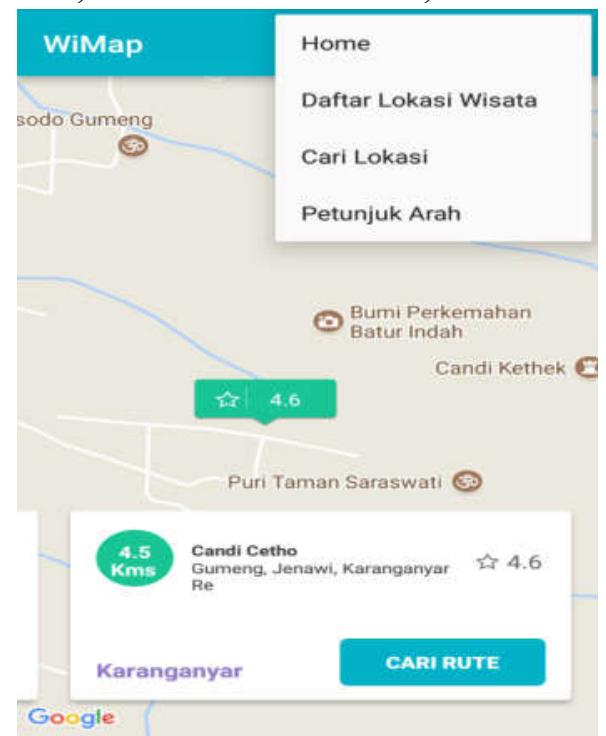

\subsubsection{Halaman Daftar Lokasi}

Gambar 4. Halaman Utama user

Pada menu Daftar Lokasi Wisata jika dipilih maka akan muncul halaman seperti pada Gambar 5. Di halaman Lokasi wisata ini terdapat alamat lokasi, deskripsi singkat lokasi dan tombol cari rute. 


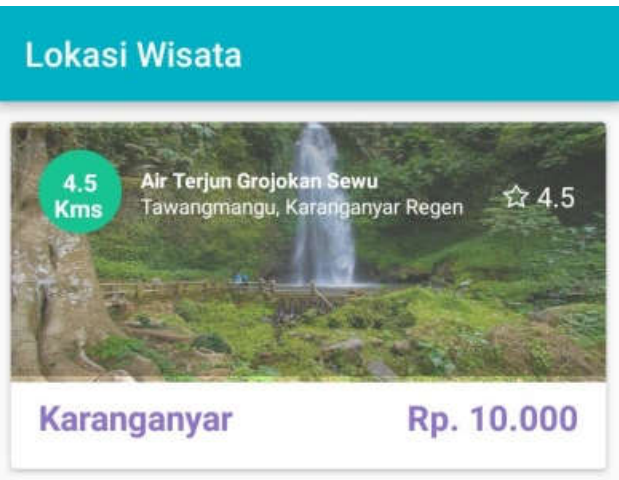

Air terjun grojokan sewu terletak tepat di bawah lereng kaki gunung lawu dengan ketinggian 80 meter. Untuk mengunjungi wisata Tawangmangu Grojogan Sewu ini kamu perlu menaklukan ribuan anak tangga terlebih dahulu.

Beberapa menyebutkan bahwa anak tangga tersebut berjumlah kurang lebih 1250 . Tangga-tangga tersebut dibangun untuk memudahkan akses menuju air terjun yang terletak jauh di bawah.

\section{RUTE}

\section{5}

Kms

Gambar 5. Halaman Daftar Lokasi

\subsubsection{Halaman Pencarian Lokasi}

Pada saat tombol Cari Rute dipilih akan muncul tampilan halaman.Rute akan otomatis terpasang ke tempat tujuan dengan titik awal rute tempat user berada.

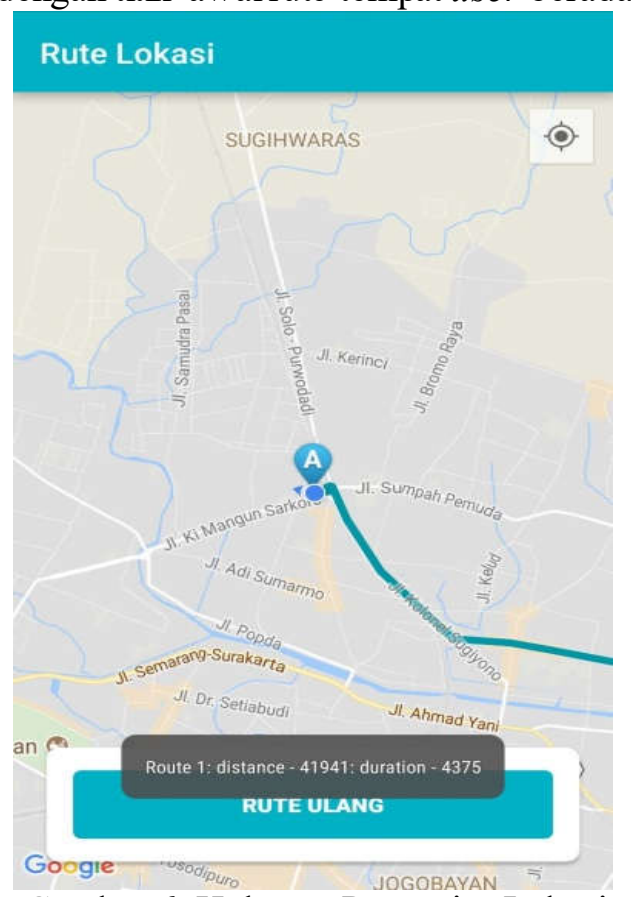

Gambar 6. Halaman Pencarian Lokasi 


\subsubsection{Halaman Pencarian Lokasi}

Halaman petunjuk arah digunakan untuk menentukan rute dari lokasi awal ke lokasi tujuan yang ditentukan oleh user.

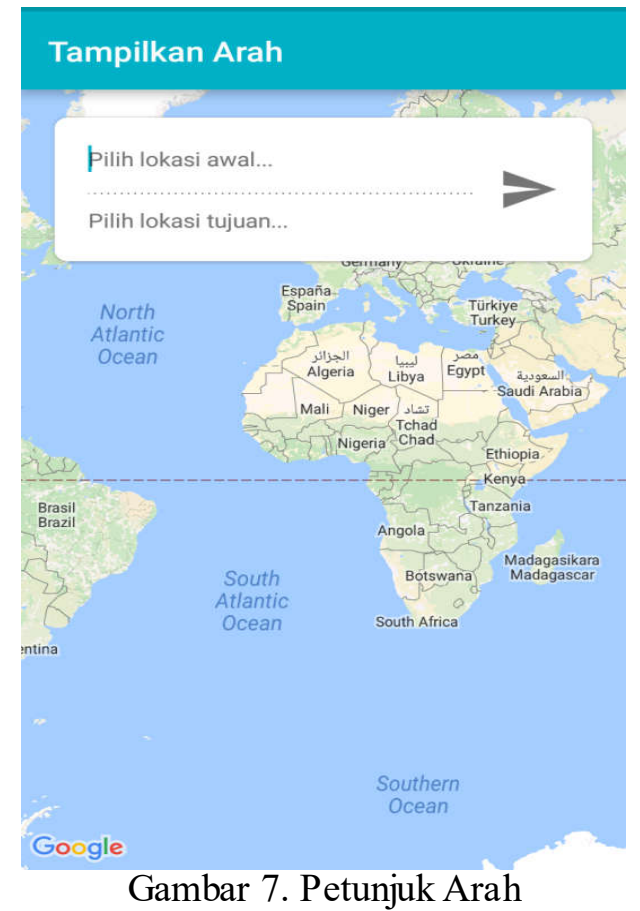

\subsection{Halaman Admin}

\subsubsection{Halaman Utama Admin}

Pada saat halaman Web diakses akan muncul halaman utama yang dapat dilihat pada Gambar 8 dibawah. Didalam Halaman Utama terdapat Menu Pengguna, Infrormasi, Logout.

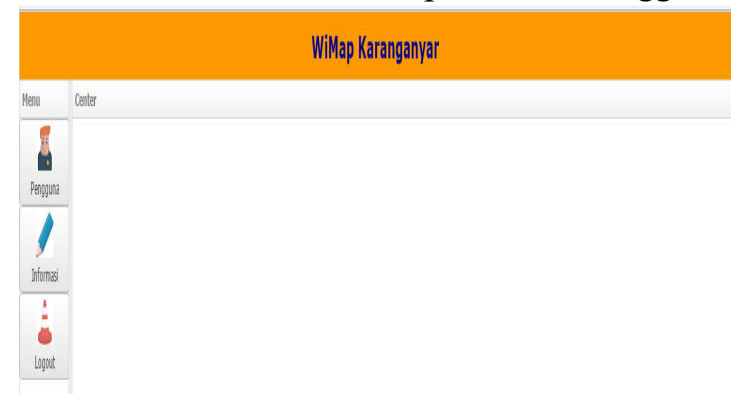

Gambar 8. Halaman Admin

\subsubsection{Halaman Tambah Admin}

Halaman Daftar Pengguna yang berisi ID, Nama,Username, dan Role. Admin juga dapat menambah, mengedit dan menghapus User.

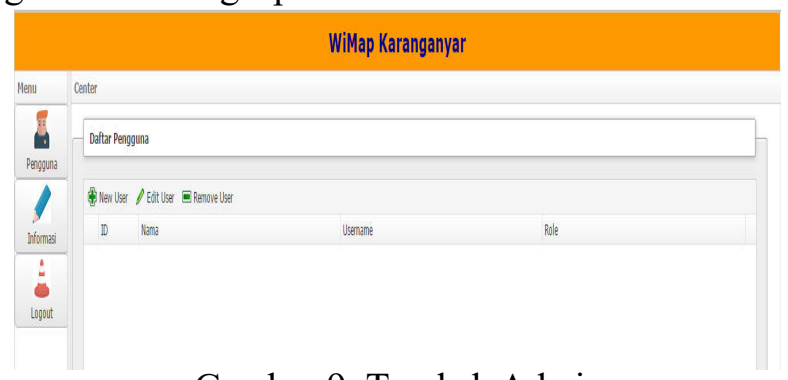

Gambar 9. Tambah Admin 


\subsubsection{Halaman Informasi}

Karanganyar.

Halaman ini berisi tentang tambah lokasi objek wisata yang ada di Kabupaten

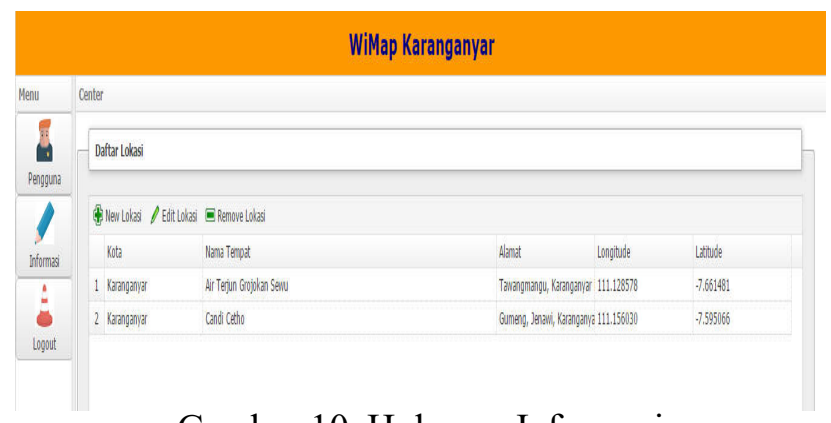

Gambar 10. Halaman Informasi

\section{KESIMPULAN}

Dengan ini penulis memberikan kesimpulan sebagai berikut:

1. Dihasilkan aplikasi sistem informasi geografis dengan Android Studio dan XAMPP yang terintegrasi dengan Google Maps di Kabupaten Karanganyar.

2. Sistem ini memberikan informasi dan sebagai alat bantu dalam memberikan informasi posisi pengguna dan menampilkan lokasi wisata dan dapat diakses oleh siapa saja.

3. Berdasarkan hasil uji dengan metode black-box, aplikasi sistem informasi geografis yang dirancang, rancangan proses pad tahapan desain sistem sesuai dengan hasil yang diharapkan.

4. Berdasarkan hasil analisis sistem yang direncanakan, dihasilkan aplikasi baru sesuai dengan yang direncanakan.

\section{SARAN}

Sistem ini masih dapat dikembangkan lebih lanjut, dengan harapan:

1. Data yang dimasukkan harus akurat terutama koordinat lokasi. Hal ini berpengaruh dalam keberadaan lokasi dalam peta dan di lapangan.

2. Untuk pengembangan lebih lanjut, setelah perhitungan jarak, penunjukkan arah lokasi bisa dikembangkan menggunakan rute (misal anak panah) yang mengikuti jalan ke lokasi yang dituju.

3. Dapat dikembangkan informasi lain yang berhubungan dengan tiap sentra yang terkain selain informasi yang sudah ada di aplikasi.

\section{DAFTAR PUSTAKA}

[1] Akbar. (2000). Tentang Pendidikan Karakter. Jakarta: Rajawali

[2] Dede. 2014. Instalasi dan Konfigurasi Jaringan Komputer Bandung:Informatika

[3] Deswita. (2006). Psikologi Perkembangan. Bandung: Remaja Rosdakarya.

[4] Gusmao, Antonio. 2013. Sistem Informasi Geografis Pariwisata Berbasis Web dan Pencarian Jalur Terpendek dengan Algoritma Dijkstra, http://jurnaleeccis.ub.ac.id/index.php/eeccis/article/view/214/186, diakses 13 Maret 2017

[5] Jogiyanto. 2005. Analisis \& Desain Sistem Informasi : Pendekatan Terstruktur, Teori dan Praktis Aplikasi Bisnis. Yogyakarta: Penerbit Andi

[6] Kristanto. 2003. Konsep dan Perancangan Basis Data. Yogjakarta: Penerbit Andi 
[7] Lestari, Puput. 2013, Sistem Informasi Geografis Berbasis Web Untuk Pemetaan Pariwisata Kabupaten Kebumen, http:/jurnal.stmikelrahma.ac.id/as sets/file/Puput\%20Lestari_stmikelrahma. pdf, diakses 13 Maret 2017

[8] Nazruddin Safaat H. 2012 (Edisi Revisi). Pemrograman Aplikasi Mobile Smartphone dan Tablet PC Perbasis Android. Informatika: Bandung

[9] Prabowo, Diky. 2009, Perencanaan dan Perancangan Arsitektur (PPA) Pusat Informasi Pariwisata dan Kebudayaan di Kabupaten Karanganyar.

[10] Prahasta, Eddy. 2002. Konsep-konsep Dasar Sistem Informasi Geografis. Bandung: Informatika

[11] Priyanto, Eko. (2013), Perancangan Sistem Informasi Geografis (SIG) Berbasis Web Untuk Penyediaan Informasi Fasilitas Dan Personalia di Universitas Lampung,http://jurnal.fmipa.unila.ac.id/index.php/semirata/article/downlod/874/693, diakses 13 Maret 2017

[12] Rahayu, Iin Tri., Ardani, Tristiadi Ardi., 2004, Observasi dan Wawancara, Bayumedia Publishing, Malang.

[13] UU Nomor 10 Tahun 2009 Tentang Kepariwisataan

[14] Wikipedia. 2017. Telepon Cerdas. https://id.wikipedia.org/wiki/Ponsel_cerdas, diakses 14 Maret 2017 